\title{
Family Support: A Caregiver Experience in Caring for Nasopharynx Cancer Patients in Yogyakarta
}

\author{
Ema Waliyanti*, Harumi Iring Primastuti \\ School of Nursing, Universitas Muhammadiyah Yogyakarta, Bantul, Daerah Istimewa Yogyakarta 55183, Indonesia
}

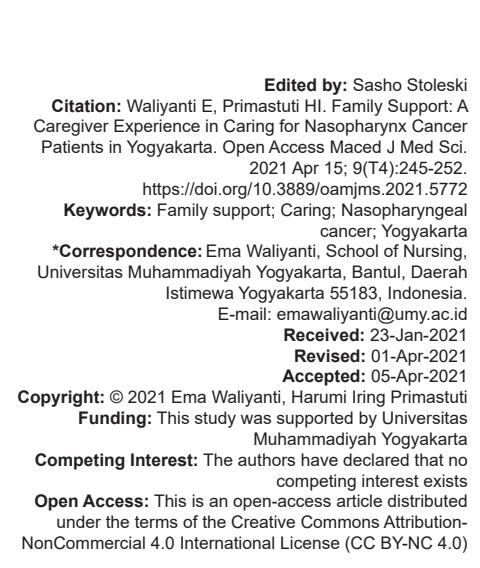

\section{Introduction}

Nasopharyngeal cancer is a carcinoma that occurs in the nasopharynx epithelial cells, which are located above the throat and behind the nose. Nasopharyngeal cancer is also a multifactorial disease that is endemic [1]. Risk factors in patients with nasopharyngeal cancer are associated with non-viral exposure and have a strong association with salted fish. Consumption of salted fish had a 1.7-7.5 times higher risk of developing nasopharyngeal cancer [2]. A research found that the nasopharynx was prone to smoking, $30-100 \%$ of smokers had an increased risk of developing nasopharyngeal cancer [3]. Moreover, a smoker tends to be male, which is in line with a research, which revealed that the risk of nasopharyngeal cancer was increased in men with a ratio of men and women was 2:1 [4].

The incidence and death rate of nasopharyngeal cancer have increased globally. The global incidence of nasopharyngeal cancer was around 129.076 new cases and 72.987 deaths. Meanwhile, there was a relatively high incidence of nasopharyngeal cancer in Indonesia, namely, 17.992 with 11.204 deaths. Specifically, the incidence of nasopharyngeal cancer in Yogyakarta was $0.03 \%$, and it was ranked fourth nationally. Based on the results of study at the Yogyakarta Health Office, the highest data were obtained, namely, in Sleman Regency with 42 hospitalization and 76 outpatients in 2016. In 2017 , there was a change, namely, 15 hospitalization and 2 outpatients, while data from the Sleman Health Office in 2018, the number of sufferers was 17 people. The death rate due to nasopharyngeal cancer globally was 50,800 deaths in 2012, while, in Indonesia, there were 28 deaths in 2012 and increased to 38 deaths in 2013 [5], [6], [7].

The prognosis of nasopharyngeal cancer at initial diagnosis was that about $80 \%$ of patients with nasopharyngeal cancer came with a condition already at an advanced stage. Therefore, the prediction of the accuracy of the prognosis and treatment failure is crucial in optimizing the therapy that the patient will undergo. Nasopharyngeal cancer patients with early stages, namely, Stages I and II, had a better prognosis than patients with nasopharyngeal cancer who were already at an advanced stage. Life expectancy in 5 years was at Stage I (72\%), Stage II (64\%), Stage III (62\%), and 
Stage IV (38\%) [3], [8]. People with nasopharyngeal cancer often felt worried and embarrassed about changes in their bodies because of the disease or treatment, such as the risk of cognitive impairment that significantly decreased memory, language, and motor performance. Another impact that arose was that the feeling of shame experienced by sufferers often caused problems in their social relationships so that most people with nasopharyngeal cancer experienced severe anxiety or even depression [9]. Nasopharyngeal cancer has physical and psychological impacts on sufferers so that family support and family roles are needed in caring for people with nasopharyngeal cancer.

Family is an essential aspect in the treatment of patients. The support provided by the family can be in the form of attention, motivation, and always being by the patient's side. It is beneficial for psychological strengthening and makes the patient more excited [10]. The role of the family in health is as a caregiver who is beside the patient for $24 \mathrm{~h}$ to meet all the needs and provide care to the patient. The caregiver's role will determine the success of treatment [11]. A research also explained that families are involved in health care because they have two reasons, namely, family support is considered a protector and, when caring for family members who are sick, the family has skills in caring for sick family members and understands more about the illness [12]. A research illustrated that the experience of caring for family members with chronic illnesses produced a different family dynamic than before. Changes in family dynamics included family response, family efforts to maintain health to care for sick family members, and health services expected by the family [13]. A research stated that there was a relationship between family support systems and quality of life in cancer patients. A good family support system means that the patient's quality of life is also good so that family support and the social environment in the patient's healing process could foster high enthusiasm for patients to recover from their illness and improve the patient's quality of life [14]. A study confirmed a significant relationship between family support and the quality of life of cancer patients. This family support would create a sense of comfort, increase self-confidence, and patients would feel loved and respected so that patients would have the motivation to recover [15]. Families are always with the patient to provide attention and motivation so that they can strengthen the patient's psychology. Besides that, the role of the family as a caregiver is beside the patient for $24 \mathrm{~h}$ to meet their needs and provide care so that the family is a determinant of the success of treatment. Based on the description above, the researchers are interested in exploring family experiences in providing care for nasopharyngeal cancer patients.

\section{Methods}

This study used a qualitative method with a phenomenological approach. The subjects in this study were patients and families of patients with nasopharyngeal cancer who lived in Yogyakarta. The sampling technique employed in this study was purposive sampling method. The inclusion criteria for sufferers were patients with nasopharyngeal cancer who lived in Yogyakarta, could communicate well, and were willing to be informants. Meanwhile, the inclusion criteria for families were nuclear families or extended families who had experience caring for patients with nasopharyngeal cancer could communicate well and be willing to be an informant. The number of informants involved in this study was 12 people, consisting of six people with nasopharyngeal cancer and six families caring for people with nasopharyngeal cancer.

This research was conducted in Sleman Regency, Yogyakarta. The time of this research was conducted from January to April 2019. The data collection technique was carried out by in-depth interviews. The research instrument utilized an interview guide containing questions about family experiences in caring for nasopharyngeal cancer patients. The interview guide's questions comprised open-ended questions that aimed to explore the desired information more deeply, while closed questions were only used to clarify and support the information obtained. One of the open questions is asking about the perception and knowledge and where are the sources of information obtained by the family in caring for nasopharyngeal cancer patients. In addition, there is also a question about how family support is for nasopharyngeal cancer patients. Finally, the question of how family-related barriers are in the care of nasopharyngeal cancer patients. The first interview process was done with the family and followed by the second interview with nasopharyngeal cancer sufferers. All interview processes lasted for 40-60 min and were carried out at the informants' house.

The data validity test in this study was performed with three methods: Data triangulation by conducting data credibility tests, namely, checking the data obtained through several sources, including families and patients with nasopharyngeal cancer. The second method was to hold a member check by checking the data that the researcher had obtained from the informant to determine the accuracy of the data, whether it was in accordance with what the informant had given. The last method was peer debriefing by discussing research results with colleagues to reduce the researchers' subjectivity. Thematic data analysis in this study was carried out using the help of Opencode 4.02 software. The researchers applied ethical principles in the form of autonomy and confidentiality during the research process. Besides, this research had received ethical approval from the ethics committee 
of the Faculty of Medicine and Health Sciences, Universitas Muhammadiyah Yogyakarta with number 573/EP-FKIK-UMY/XI/2018.

\section{Results}

The results showed that three major themes could describe family experiences providing support to patients with nasopharyngeal cancer during treatment, including (1) factors that influence the family in caring for nasopharyngeal cancer patients, (2) family process in providing care, and (3) obstacles faced by families. Factors that influenced families in caring for patients with nasopharyngeal cancer included family perceptions of caring for patients, family knowledge of the disease, and family sources of information. Some of these things would affect the family process in providing care to sufferers. Aspects of the family process in providing care to sufferers included family support, family communication, and previous medication. During the family process in providing care, there were several obstacles faced by the family. Obstacles faced by families during the family process in providing care were transportation, administrative, and financial obstacles. It is shown in Figure 1:

\section{Factors affecting family in caring}

Three factors influenced families in caring for patients with nasopharyngeal cancer in Yogyakarta, namely, the family's perception in caring for patients, family knowledge about nasopharyngeal cancer, and sources of information obtained by the family. The first factor is the perception of the family in caring for

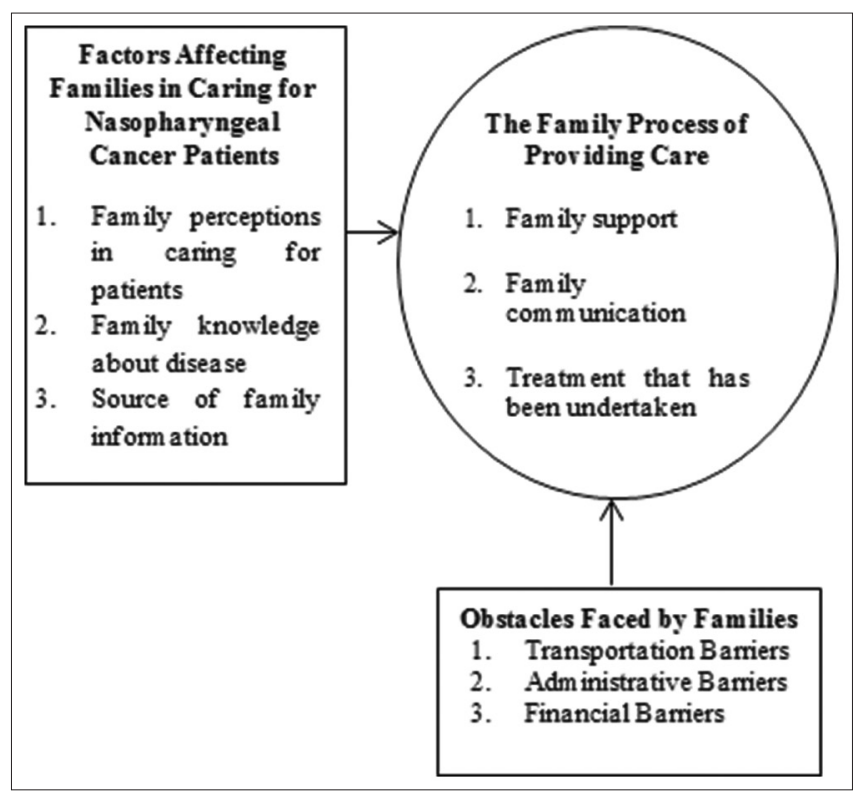

Figure 1: Family experiences in caring for patients with nasopharyngeal cancer nasopharyngeal cancer patients. The family stated that in caring for people with nasopharyngeal cancer, they had to prepare food, medicine, and clothes for the patient while the patient was sick. Sometimes, when preparing food, it had to be what a person with nasopharyngeal cancer wanted. It was indicated by the informant's statement, as follows:

"Yes, what, yeah, it is normal, maybe because it is just making food, just like that, and reminds if they have not taken medicine, that is all (a small child's voice is heard)" (Family, 56-year-old woman)]

"So what should I do, just when time eats, I have to ask, "What do you want to eat? "yes so, what he/she wants to eat. If the food is not wanted, then it will be mubadhir, also a waste of it. Therefore, if hel she wants to eat something, I just buy it right away. As long as it does not break the prohibition, I will give it. However, if those who violate the prohibition, I will not give them hehehe (laughs)." (Family, 43-year-old woman)]

"Yes, preparing the clothes and also the medicine...." (Family, 57-year-old woman)

The second factor is family knowledge about the disease. The results of this study indicated that, according to the family, nasopharyngeal cancer is a nasal tumor, and some said that nasopharyngeal cancer is nose cancer. The cause of nasopharyngeal cancer, according to the family, was due to smoking. The family also said that the treatment of nasopharyngeal cancer was only chemotherapy and rays and no surgery. It was in accordance with the informant's statement, as follows:

"It is a tumor. What tumor, I forgot what it meant. Oh, the tumor is in his nasal cavity." (Family, 42-year-old woman)

"That is nose cancer. In my opinion, yes, nose cancer. Here (holding and pointing at the nose) is a lump behind the nose. " (Family, 43-year-old woman)

"Yes, just coughing. Maybe because of the smoking if I thought, maybe because of the smoking. Because he is a heavy smoker, when it comes to eating, it is normal,..." (Family, 56-year-old woman)

"Yes, the treatment is not with surgery but with chemo and rays ..." (Family, 61-year-old man)

The third factor is the source of family information. This study's results revealed that families' source of information to find out about nasopharyngeal cancer was from doctors, reading books in hospitals, searching on the internet, and watching television. It was in accordance with the informant's statement, as follows:

"From the doctor from the results of the examination. All the families, right after finishing the CT-Scan and all kinds of things, we just had to wait, then the family was asked to go there and was told that 
it turned out that Mr. A had experienced..." (Family, 42-year-old woman)]

"I know from TV hehehe (laughs)..." "Sometimes, reading what available in the hospital. There are books. Sometimes, given guidelines for caring for sick people, there is a prohibition for people with cancer." (Family, 43 years old)

"... then after we found out, we were told that it was nasopharyngeal cancer, we were busy looking for it on the internet. There is a lot of information about nasopharyngeal cancer, most of which say that the cause is unknown ... "(Family, 61-year-old man)

\section{The family process of providing care}

This study's results denoted that during the family process providing care, it consisted of family support, family communication, and family medication. This family support comprised emotional support by providing support; informational support by providing information about the disease; instrumental support by delivering examinations and accompanying patient activities; appreciation support by still respecting the patient's opinion but was not involved in decisionmaking; and spiritual support by reminding and helping patients in worship. The support was in accordance with the informant's statement, as follows:

"My wife always provides support for me, sometimes also friends. The friend is encouraging" (Patient, 48-year-old man)

"We motivated by the presence of cellphones, we often video call our grandchildren and so on ......., that is in order to motivate not to give up" (Family, 61-year-old man)]

"Yes more or less tell" "Yes, what was conveyed from the doctor was that the grilled food needs to be avoided. Then, foods that are preserved....... with salt are avoided. Also, another one here is still tough food (Family, 61-year-old man)

"Every day, the kids eat here, so we gather. When eating, we are here, then the father sleeps here, so we gather."(Family, 43-year-old girl)

$P$ : “....... family in the sense that it still respects the father or not, from before the illness and after the illness. Is there a change, mom?"

I: "yes, God willing, still (hehehhe)" (Family, 57-year-old woman) not, sir?"

$P$ : "your family often reminds you to pray or

I: "Yes. Especially daughter and wife, who often reminds me to pray..." (Patient, 61 years old man)

Apart from providing support, families also communicated with patients. Family communication with patients usually discussed the patient's medication. This communication was carried out at any time by the family. It was evidenced by the informant's statement, as follows:

"Yes, every time, sis, because there are only two of us here, hehehe" (Family, 57-year-old woman)

Besides, there was one family who rarely communicated with the family. It was caused by the family when they came home tired, and the patient was just silent, so there was no communication. It was in accordance with the informant's statement, as follows:

"Yes, how do I communicate, I rarely communicate ...hahaha, the father is silent, when I come home, I am tired, there is no communication whatsoever." (Family, 56-year-old woman)

This study's results also indicated three types of treatment taken by families to treat patients with nasopharyngeal cancer. These treatments were alternative medicine, herbal medicine, and medical treatment. Alternative medicine was undertaken by families and patients because, at that time, they did not know if they had nasopharyngeal cancer, so they used alternative medicine first. It was in accordance with the informant's statement, as follows:

"Hemm, yes, we go to an alternative first because it was said to be the blood clotting, then I said," let us try it first." (Family, female 43 years)

The next treatment for nasopharyngeal cancer patients and families was herbal treatment. Herbal treatment was using herbs. The family said that the herbal medicine used as an herbal treatment for nasopharyngeal cancer patients consumed Niker leaves and bitter melon stew. It was in accordance with the informant's statement, as follows:

"If the herbs are niker leaves, then the bitter melon is boiled and drink the water." (Family, 61-yearold man)

The last treatment experienced by families and nasopharyngeal cancer patients was medical treatment. The family said that nasopharyngeal cancer patients had to undergo chemotherapy and, before chemotherapy, patients had to do conditioning their bodies first. It was supported by the informant's statement, as follows:

"... The chemotherapy is carried out six times, once the chemo is $5 \times 24$ hours, so the chemo alone is $5 \times 24$ hours, so usually, we are in the hospital for about eight or ten days every time the chemo. It is because sometimes conditioning and so on so requires blood transfusions and so on" (Family, male 61 years).

\section{Obstacles faced by families}

This study's results indicated that the family process in caring for patients with nasopharyngeal cancer had experienced several obstacles. These obstacles were in the form of transportation barriers, 
administrative barriers, and financial constraints. The first obstacle was the transportation barrier, where there were often obstacles in transportation. It occurred due to people with nasopharyngeal cancer who could not yet use motorbikes and had to ask neighbors for help. It happened in the early days after the patient was operated on and was caused because the patient with nasopharyngeal cancer was still weak and had a tube inserted. Families had obstacles in terms of transportation when going to the hospital. This obstacle was caused by patients with nasopharyngeal cancer who were weak and had a hose installed that has not been removed so that they could not go to the hospital on a motorbike, so they had to ask for help from a neighbor who had a car. It was the cause of increasing costs in treatment so that this barrier would have an impact on the family financially.

The second obstacle faced by families was administrative barriers. This administrative obstacle was felt when the family took care of health insurance. Health insurance management was hampered when processing referral letters at the health center. The family felt that taking care of health insurance at the health center had to wait long queues. The management of health insurance was also hampered or had difficulties when the family took care of administration in hospitals outside the region. It was because the family had never been to the hospital and did not know the flow of administrative arrangements.

Apart from the above obstacles, the third obstacle that families faced while caring for nasopharyngeal cancer was financial. This financial obstacle was caused because not all had health insurance and other needs in the treatment process at their own expense. Especially after suffering from nasopharyngeal cancer, the family had to work, and only one person worked while many needs had to be met so that this financial barrier became an obstacle for the family in carrying out treatment and medication. It was based on the informant's statement, as follows:

$P$ : "For example, the transportation for medical treatment, is there any obstacle ma'am?"

woman)]

I: "yes, there are often" (Family, 56-year-old

"The difficulty is if you want to go, miss." "hehehe yes the transportation" (Family, 57-year-old woman)]

"If I do the administration, you know, we also have trouble because there we do not know sometimes, then we do not know where yo o, because we have never been there and were there for the first time ..." (Family, 43-year-old woman)]

"The obstacle is that it requires funds, right? Even though in the hospital, most of it is covered by BPJS, but outside of that it has to be from us ..." (Family, 61-year-old man)]

\section{Discussion}

\section{Factors affecting family in caring}

This study's results revealed that the factors that influenced the family in caring, namely, the family's perception in caring for patients with nasopharyngeal cancer, were to fulfill the patient's needs, including food, clothing, and the drugs consumed. It was one of the roles of the family in meeting the basic human needs of patients. According to a research, it stated that someone who plays a role in the moderate caregiving stage that is often carried out includes providing daily care to patients, including preparing meals, assisting in preparing toiletries, preparing clothes, getting medicines, and escorting them to health service centers [16].

The second factor influencing the family in caring for patients was the family's knowledge of the disease. The results of this study indicated that according to the family, nasopharyngeal cancer is a tumor or nose cancer caused by smoking and anchovies. Treatment of nasopharyngeal cancer, according to the family, was chemotherapy and rays and not surgery. The family's knowledge was good because the family has already known about the diseases suffered by patients, starting from the definition, causes, and treatment of nasopharyngeal cancer patients. In accordance with a research, family knowledge would determine how the family provided care. If the family's knowledge was lacking, there would be mistakes in carrying out treatment; on the other hand, if the family's knowledge was good, the patient's care would be good [17].

The knowledge that this family had would affect how the family provided care for people with nasopharyngeal cancer. When the family had good knowledge about the disease, the family would better treat patients with nasopharyngeal cancer. A research stated that the knowledge possessed by a person was influenced by the level of education [18]. Therefore, someone who had a low level of education would become an obstacle to that person developing an attitude toward receiving new information and values that have never been accepted before.

Besides, the factor that influenced the family in caring was the source of family information. This study's results were one of the family's efforts in obtaining information about nasopharyngeal cancer, namely, through information delivered by doctors, reading books in hospitals, searching on the internet, and watching television. Families have been good at finding information through several sources. The number of sources of information obtained by the family would further increase the family's knowledge about nasopharyngeal cancer in patients so that patients had a good quality of life, in line with a research, which affirmed that the source of information in seeking treatment was carried out independently by the family. The source of 
family information was either through television, media, or searching the internet. Some families also chose to seek information by asking doctors about the disease and the treatment process [19]. Furthermore, the family got information about the types of drugs and their use from the chemotherapy nurse.

The sources of information used by the family are in accordance with a research, which asserted that the main information was obtained from a doctor and then information from a friend or relative who had the same disease. Other sources for immediate information are the internet, books, and communities. Information that is usually sought is regarding symptoms of the disease, disease severity (stage), transmission and treatment, as well as diet or lifestyle that must be followed [20].

\section{The family process of providing care}

This study's results signified that family support provided to patients with nasopharyngeal cancer was emotional support, informational support, instrumental support, appreciation support, and spiritual support. Family support was provided by the family to patients with nasopharyngeal cancer to reduce the negative impact that could occur on the patient. The negative impact could be in the form of satisfaction with treatment, which would cause new problems in patients with nasopharyngeal cancer. Agreed with a research that found that the support given to patients would have a positive impact if given appropriately, but if given inappropriately and inadequately, it would have a negative impact on the patient [21].

Some of the family support that had been done by the family from this study's results is in accordance with a research, which mentioned that family support consisted of appraisal support, informational support, emotional support, and instrumental support. This family support would affect the cure for nasopharyngeal cancer [22]. A study uncovered that family support for the patient would provide peace to the patient so that the patient's hope for recovery would increase [18]. It is in accordance with a research, which discovered that there was a significant relationship between family support and quality of life for cancer patients. This family support would create a sense of comfort, increase self-confidence, and patients would feel loved and respected so that patients would have the motivation to recover [15]. According to a study, palliative care in cancer patients had a relationship with the patient's quality of life. Palliative care in cancer patients had top priority, namely, on the patient's quality of life and not on the patient's recovery [23].

This study found that spiritual support was given by families in caring for patients with nasopharyngeal cancer by reminding patients to pray. A research affirmed that when a person has high trust in God, it will lead to a more positive attitude, gain inner satisfaction, and get enthusiasm naturally [15].
In addition to family support, there was family communication, one of the family processes in caring for patients with nasopharyngeal cancer. The family said that they rarely communicated with the family because when they came home from work, they were tired. However, when the family was at home, they communicated with people with nasopharyngeal cancer at any time. This study's results indicated that in communicating with patients with nasopharyngeal cancer, according to family conditions, there were families who did not have activities outside the home, they would communicate more often with patients with nasopharyngeal cancer. In contrast, some families replaced the role of people with nasopharyngeal cancer as backbones of the family, so they had limitations in communicating. Meanwhile, family communication influenced the motivation of patients with nasopharyngeal cancer in dealing with the disease they were suffering. A study found that when a person made interpersonal interactions with cancer patients, it would indirectly motivate them. This interaction must pay attention to the five components of interpersonal communication's effectiveness, including empathy, positive attitude, openness, supportive attitude, and equality [24].

This study's results showed that one of the family processes in providing care for patients with nasopharyngeal cancer was a treatment that was undertaken by the family for patients with nasopharyngeal cancer. The treatment that had been undertaken could be in the form of alternative medicine, herbal medicine, and medical treatment. Treatment carried out by the family for patients with nasopharyngeal cancer started from the appearance of early signs and symptoms of nasopharyngeal cancer. The treatment that the family was undergoing was carried out alternately. It was due to the late medical diagnosis of nasopharyngeal cancer because nasopharyngeal cancer does not have distinctive signs so that in the initial range of signs and symptoms until the medical diagnosis of nasopharyngeal cancer was established, the family chose to try non-medical treatments. Nonmedical treatment undertaken by the family began with alternative medicine and herbal remedies. The results of this study are in accordance with a research that the treatment-seeking behavior of patients with nasopharyngeal cancer was through medical treatment and switching to alternative medicine, but then returning to medical treatment. However, some used concurrent medicine or as a complementary therapy [25]. A research asserted that due to high health costs, health services are not the primary choice. People preferred to undergo traditional and complementary medicine [13].

\section{Obstacles faced by families}

Obstacles faced by families were transportation barriers, administrative barriers, and financial constraints. This study's results showed that the family had obstacles 
in terms of transportation when going to the hospital. This obstacle was caused by patients with nasopharyngeal cancer who were weak and had a hose installed that has not been removed so that they could not go to the hospital on a motorbike, so they had to ask for help from a neighbor who had a car. It would be the cause of increasing costs in treatment. Thus, this obstacle would influence the financial impact of the family. A study uncovered that the travel burdens that families and patients undertook to health services would influence the diagnosis and proper treatment of cancer [26]. Therefore, it would have an impact on the patient's quality of life. A research also stated that transportation barriers would impact one's access to health services so that it would affect adherence to treatment. Patients with low-income transportation barriers became a burden because they were not insured [27]. Thus, many patients could not access health services, which resulted in high visits to the emergency room.

The second obstacle in this study was administrative barriers. Administrative barriers were in terms of administering health insurance. The family felt that taking care of health insurance at the health center had to wait long queues.

Besides, families also found it difficult to take care of administration or health insurance when they were outside the region. It was because the family did not know the flow of administrative management in the area. A research said that difficulties in administering administrative arrangements at health insurance facilities at the hospital, long queues at the health center, and expensive medical health services were difficulties faced by families when undergoing the treatment process [13]. Other research also stated that the barriers to providing specialized care were related to incomplete referrals [28].

Besides, family obstacles faced by families were a financial constraint. This research's result was that when the treatment process was not all families had health insurance, and families who have already had health insurance for other needs apart from treatment still had to use personal costs. Thus, this financial barrier became an obstacle for families in carrying out treatment and medication. A study stated that financial hardship is a common problem faced by people with cancer [29]. Other research also said that the barrier to treating patients with cancer is financial. The family spent its time caring for patients and decided to stop working so that, in undergoing treatment, they had to be constrained by funds because they were no longer working [30].

\section{Conclusion}

Family support provided while caring for patients with nasopharyngeal cancer was in the form of emotional, informational, instrumental, appreciation support, spiritual support, and regular communication in accompanying patients with nasopharyngeal cancer while undergoing medical and non-medical treatment. Family perceptions, family knowledge, and family sources of information were factors that influenced families in caring for patients. Besides, in the process of providing care to patients with nasopharyngeal cancer, there were obstacles faced by families, such as transportation, administration, and financial constraints. Researchers recommend to families caring for nasopharyngeal cancer patients to provide support both emotionally, informational, instrumental, rewarding, and spiritual. Spiritual support is important because it will give more approach to God so that this support can improve the patient's quality of life.

\section{Acknowledgments}

The researchers thank the informants who participated in the research process and related parties, such as the health center and village government, who had facilitated this research process. Besides, the researchers also thanked UMY for funding this research.

\section{References}

1. Estania AP, Sulistyo $H$, Wahyono DJ. Relative expression of BRLF1 epstein-barr virus mRNA from tumor tissue biopsy in paraffin block as a marker of biological pathogenesis of nasopharyngeal carcinoma. J Biosfera. 2017;34(2):59-66. https://doi.org/10.20884/1.mib.2017.34.2.409

2. Ariwibowo $H$. Risk factors for nasopharyngeal carcinoma. J CDK 204. 2013;40(5):4.

3. Wijaya FO, Soeseno B. Early detection and diagnosis of carcinoma nasopharynx. J CDK-254. 2017;44(7):478-81.

4. Arditawati Y. Analisa Hubungan Antara Faktor Risiko dengan Tipe Hispatologik pada Karsinoma Nasofaring. Semarang, Indonesia: Doctoral Dissertation Faculty of Medicine Universitas Diponegoro; 2011.

5. Infodatin Pusat Data dan Informasi Kementerian Kesehatan RI Stop Kanker. Available from: http://www.depkes.go.id/ resources/download/pusdatin/infodatin/infodatinkanker.pdf. [Last accessed on 2020 Dec 20]

6. World Health Organization. The Global Cancer Observatory Nasopharynx. Geneva: World Health Organization; 2019.

7. World Health Organization. The Global Cancer Observatory Indonesia. Geneva: World Health Organization; 2020.

8. Faisal HH. Gambaran Karakteristik Karsinoma Nasofaring dan Faktor-Faktor yang Mempengaruhi Prognosis. Indonesia: Undergraduate Thesis Universitas Indonesia; 2016.

9. Tang Y, Luo D, Rong X, Shi X, Peng Y. Psychological disorders cognitive dysfunction and quality of life in nasopharyngeal carcinoma patients with radiation-induced brain injury. PLoS One. 2012;7(6):e36529. https://doi.org/10.1371/journal.pone.0036529 


\section{PMid:22701557}

10. Wahyuni D, Huda N, Utami GT. Phenomenological studies: Experience of advanced cancer patients undergoing chemotherapy. J Online Mahasiswa Bidang IImu Keperawatan. 2015;2(2):1041-7.ttps://doi.org/10.32584/jikm.v2i1.278

11. Daulay NM, Setiawan S, Febriany N. Family experience as a caregiver in caring for stroke patients at home. J Keperawatan Padjadjaran. 2014;2(3):161-70. https://doi.org/10.24198/jkp. v2n3.4

12. Park M, Chesla CK. Understanding complexity of Asian American family care practices. Arch Psychiatr Nurs. 2010;24(3):189-201. https://doi.org/10.1016/j.apnu.2009.06.005

PMid:20488345

13. Kartika AW, Permatasari H, Wiarsih W. Family Experience in Caring for Chronic Pain Sufferers. J Keperawatan Indones. 2015;18(1):51-8. https://doi.org/10.7454/jki.v18i1.398

14. Widari NP, Serlinda PM. Support system keluarga dengan kualitas hidup pasien kanker di yayasan kanker Indonesia Surabaya. J Keperawatan. 2018;7(2):106. https://doi. org/10.47560/kep.v7i2.106

15. Susanti NL. Family support in improving the quality of life of cervical cancer patients. J Ners Lentera. 2017;5(2):106-15. https://doi.org/10.20473/jn.v11i12016.112-117

16. Werdani YD. Effect of caregiving in cancer patients on the leve of caregiver burden. J Ners Midwifery. 2018;5(3):249-56. https:// doi.org/10.26699/jnk.v5i3.art.p249-256

17. Huda N, Sitorus R. Family Experience Caring for Cachexia Patients in Advanced Stage Cancer. J Parallela. 2014;1(1):25-34.

18. Afiyah RK. Family support affects adaptability (applying Roy's Adaptation model) to cancer patients at the East Java branch of the Indonesian Cancer Foundation. J Health Sci. 2017;10(1):150. https://doi.org/10.33086/jhs.v10i1.150

19. Rahayuwati L, Ibrahim K, Komariah M. Treatment options for breast cancer during chemotherapy: a case study. J Keperawatan Indones. 2017;20(2):118-27. https://doi. org/10.7454/jki.v20i2.478

20. Hadisiwi P, Arifin HS. Communication experience of people with cervical cancer in seeking treatment information in West Java. J Kajian Komunikasi. 2018;6(1):51. https://doi.org/10.24198/jkk. v6i1.15388

21. Witjaksono AM, Maulina VV. Gambaran perceived social support
Perceived social support in patients with advanced cancer who are undergoing palliative care. J Psikogenesis. 2016;4(1):12. https://doi.org/10.24854/jps.v4i1.514

22. Sari DP. Gambaran Dukungan Keluarga pada Pasien Kanker yang Menjalani Terapi di RSUD Panembahan Senopati Bantul. Yogyakarta: Undergraduate Thesis Universitas Muhammadiyah Yogyakarta; 2014. https://doi.org/10.30989/mik.v6i1.157

23. Anita A. Palliative care and quality of life for people with cancer. $J$ Kesehatan. 2016;7(3):508. https://doi.org/10.26630/jk.v7i3.237

24. Surry K, Yahya M. Interpersonal communication of C-four members in motivating children with cancer in Aceh (descriptive qualitative study in the children cancer care community (C-Four) Aceh). J Ilmiah Mahasiswa FISIP Unsyiah. 2018;3:159-68. https://doi.org/10.25124/liski.v3i2.1056

25. Waliyanti E, Tetra Dewi FS, Supriyati S, Renske F. Treatmentseeking behaviour of nasopharyngeal cancer patients in Yogyakarta, Indonesia. Pan Afr Med J. 2018;29:98. https://doi. org/10.11604/pamj.2018.29.98.12817 PMid:29875979

26. Ambroggi M, Biasini C, Del Giovane C, Fornari F, Cavanna L. Distance as a barrier to cancer diagnosis and treatment: Review of the literature. Oncologist. 2015;20(12):1378-85. https://doi. org/10.1634/theoncologist.2015-0110

27. Syed ST, Gerber BS, Sharp LK. Traveling towards disease: Transportation barriers to health care access. J Community Health. 2013;38(5):976-93. https://doi.org/10.1007/ s10900-013-9681-1 PMid:23543372

28. Zuckerman KE, Perrin JM, Hobrecker K, Donelan K. Barriers to Specialty Care and Specialty Referral Completion in the Community Health Center Setting. J Pediatr. 2013;162(2):409414. https://doi.org/10.1016/j.jpeds.2012.07.022 PMid:22929162

29. Altice CK, Banegas MP, Tucker-Seeley RD, Yabroff KR. Financia hardships experienced by cancer survivors: A systematic review. J Natl Cancer Inst. 2017;109(2):djw205. https://doi.org/10.1093/ jnci/djw205

PMid:27754926

30. Handian FI, Widjajanto PH, Sumarni DW. Motivation, barriers and strategies of poor family parents in caring for children with acute lymphoblastic leukemia (ALL). J Care. 2017;5(1):77-91. 